\title{
Электрофизические и оптические свойства органических светодиодных структур с эмиссионным слоем ЯК-203
}

\author{
А.В.Войцеховский ${ }^{1,2)}$, С.Н.Несмелов ${ }^{1)}$, С.М.Дзядух ${ }^{1)}$, А.П. Коханенко ${ }^{1)}$ \\ ${ }^{1}$ Национальный исследовательский Томский государственный университет, Томск, 634050, пр. \\ Ленина, 36 \\ ${ }^{2}$ Сибирский физико-технический институт ТГУ, Томск, 634050, пл. Новособорная, 1 \\ тел:+7 (3822) 41-2772, факс:+7 (3822) 41-2772, эл. почта: vav43@ mail.tsu.ru
}

DOI 10.34077/RCSP2019-164

Исследования свойств новых типов многослойных систем необходимы для разработок органических светоизлучающих диодов (ОСИД), которые востребованы для создания дисплеев, систем освещения большой площади, транзисторов и фотоэлектрических устройств [1]. Одной из перспективных является ОСИД структура ITO/PEDOT:PSS/ $\alpha-\mathrm{NPD} /$ ЯK-203/BCP/LiF/Al. Эмиссионный слой создавался из вещества ЯК-203 (2-N,2-N,8-N-тетракис(4-метоксифенил)-(дибензотиофен-5,5диоксид)-2,8-диамин), в котором наблюдается эффект термоактивированной люминесценции, что приводит к замедлению электролюминесценции при скоростях интерконверсии, близких к скорости излучательных процессов. В данной работе свойства ОСИД структуры со слоем ЯК-203 исследованы при помощи методов адмиттанса и переходной электролюминесценции.

Показано, что при напряжениях, соответствующих эффективной излучательной рекомбинации носителей заряда, наблюдается значительное уменьшение дифференциальной емкости структур. Частотные зависимости приведенной проводимости светодиодных структур хорошо согласуются с результатами численного моделирования в рамках метода эквивалентных схем. Изменения частотных зависимостей адмиттанса при изменении температуры наиболее выражены в диапазоне 200300 К и менее заметны в области температур 8200 К. Для определения подвижности носителей заряда предложено использовать методику, основанную на измерении частотных зависимостей мнимой части импеданса структур [2,3]. Изучены зависимости подвижности носителей заряда от напряжения смещения и температуры (рисунок). Найденные значения подвижности несколько меньше значений, определенных методом переходной электролюминесценции.

Исследования проведены при финансовой поддержке РФФИ и Администрации Томской

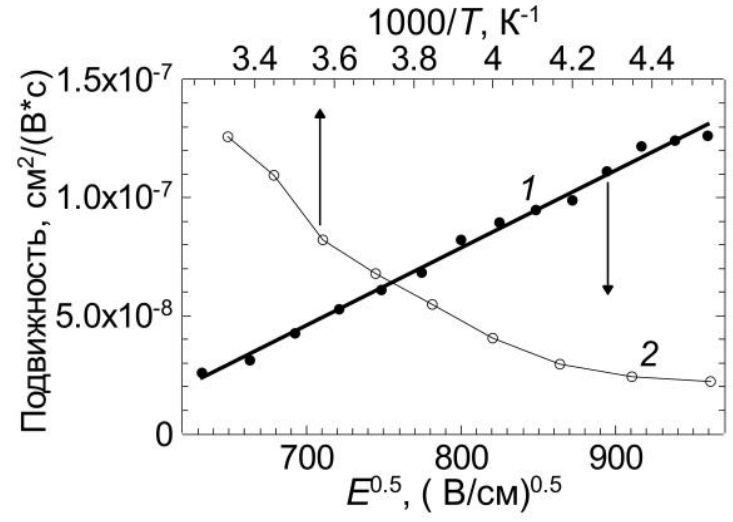

Рисунок. Зависимости подвижности носителей заряда от квадратного корня из напряженности электрического поля при температуре 300 К (кр. 1) и температуры при напряжении 6 В (кр. 2) области в рамках научного проекта р_а № 18-43-700005.

\section{Лumepamypa}

[1] S.S.Sun, L.R.Dalton. Introduction to organic electronic and optoelectronic materials and devices. Boca Raton: Taylor \& Francis, CRC Press, 2016. 963 p.

[2] D.C.Tripathi, et al. // Appl. Phys. Lett. 2011. V. 98, No. 3. P. 14.

[3] J.M.Fernandes, et al. // Superlatt. Microstr. 2015. V. 83. P. 766-775. 